\title{
Peningkatan Efisiensi Tenaga Kerja pada Lintasan Assy Wheel dengan Metode Line Balancing Ranked Positional Weight
}

\author{
Muhammad Ilham Akbar Hariyanto ${ }^{1}$, Hery Hamdi Azwir ${ }^{1}$ \\ 1) Faculty of Engineering, Industrial Engineering Department, President University \\ Jl. Ki Hajar Dewantara \\ Kota Jababeka,Cikarang, Bekasi - Indonesia 17550

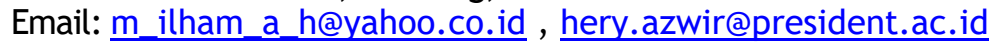

\begin{abstract}
ABSTRAK
Pada proses produksi sepeda motor di PT XYZ dilakukan berbagai proses manufaktur dan salah satu nya adalah proses Assy Wheel. Proses Assy Wheel untuk type K93X yang dilakukan pada PT XYZ memiliki efisiensi lintasan yang cukup rendah. Hal tersebut terjadi karena ada beberapa stasiun kerja yang tidak seimbang yang mana kondisi tersebut cukup merugikan bagi perusahaan, sehingga hal tersebut perlu diminimalkan atau dihilangkan. Salah satu cara meminimalkan stasiun kerja yang tidak seimbang adalah dengan menyeimbangkan lintasan kerja dengan metode RPW (Ranked Positional Weight). Metode ini dilakukan dengan cara membuat precedence diagram, menentukan pembobotan posisi untuk setiap elemen kerja, mengurutkan elemen kerja berdasarkan posisi peringkat, penempatan elemen kerja pada stasiun kerja, menempatkan sisa waktu pada sebuah operasi dengan urutan selanjutnya pada stasiun kerja. Setelah dilakukan proses analisis pada Lintasan Assy Wheel ditemukan elemen kerja pada stasiun kerja yang perlu diubah dan diseimbangkan. Elemen kerja digabungkan pada stasiun kerja selanjutnya sehingga efisiensi lintasan meningkat dari $74 \%$ menjadi $95 \%$, dan jumlah stasiun kerja dan tenaga kerja berkurang dari empat menjadi dua.
\end{abstract}

Kata Kunci: kapasitas produksi, line assembling, line balancing, cycle time, efisiensi lintasan

\section{ABSTRACT}

In the production of motorcycles at PT XYZ, there are various manufacturing processes and one of them is the Assy Wheel process. The Assy Wheel process for the K93X type performed on PT XYZ has a fairly low track efficiency. This happens because there are some unbalanced work stations where the conditions are quite detrimental to the company, so they need to be minimized or eliminated. One way to minimize unbalanced work stations is by balancing work tracks with the RPW (Ranked Positional Weight) method. This method is done by making a precedence diagram, determining the weighting of positions for each work element, sorting work elements by ranking position, placing work elements on a work station, placing the remaining time on an operation in the next sequence at the work station. After the analysis process is carried out on the Assy Wheel Track, there is a work element at the work station that needs to be changed and balanced. Work elements are combined at the next work station so that the track efficiency increases from $74 \%$ to $95 \%$, the number of work stations and labor is reduced from four to two.

Keywords: production capacity, line assembly, line balancing, cycle time, line efficiency

\section{Pendahuluan}

Saat ini setiap perusahaan manufaktur berusaha memaksimalkan semua peralatan yang tersedia guna terciptanya efisiensi. Efisiensi yang tinggi sering kali kontraproduktif terhadap kapasitas produksi, karena efisiensi yang tinggi biasanya disertai dengan meminimalisir penggunaan peralatan sehingga harus didapatkan hal yang seimbang antara penggunaan peralatan dan kapasitas yang berdampak pada efisiensi pada lini produksi.

Line Balancing menggunakan metode Ranked Positional Weight telah digunakan pada perusahaan manufaktur untuk penyeimbangan lintasan seperti penelitian yang telah dilakukan oleh (Kays, Emrul, dkk., 2017). Dalam salah satu penelitian dikatakan bahwa Line Balancing dengan menggunakan metode Rank Positional Weight adalah metode yang paling banyak diaplikasikan dalam industri (Manaye, 2019). Di antara industri yang 
mengaplikasikannya adalah industri sepatu bola (Afifuddin, 2019), industri rokok (Prabowo, 2016), industri farmasi (Astuti \& Edy purwanto, 2019, dan industri alat berat (Azwir \& Nugraha, 2020).

Pada proses Assy Wheel yang dilakukan PT XYZ ditemukan efisiensi lintasan yang cukup rendah yaitu sebesar 74\%. Hal tersebut terjadi karena ada stasiun kerja yang tidak seimbang antara jumlah stasiun kerja dan elemen kerja yang dilakukan. Pada stasiun kerja insert valve memiliki cycle time 10.32 detik sedangkan pada proses Final Inspection memiliki cycle time 22,41 detik. Berdasarkan data tersebut dapat diketahui bahwa terdapat perbedaan waktu yang cukup signifikan antar proses di lintasan Assy Wheel. Hal ini cukup merugikan bagi perusahaan karena berdampak adanya tenaga kerja yang berlebih pada proses assy wheel, maka dari itu perlu dilakukan usaha untuk meminimalkan atau menghilangkan beberapa stasiun kerja sehingga efisiensi lintasan dapat meningkat dan jumlah tenaga kerja dapat diminimalisir.

\section{Metodologi}

Metodologi penelitian merupakan kerangka kerja secara sistematis yang akan menggambarkan tahapantahapan untuk mengidentifikasi, merumuskan, menganalisis, memecahkan dan menyimpulkan suatu masalah sehingga lebih terarah dan beraturan dalam melakukan penelitian. Dalam penyusunan penelitian ini, kerangka penelitian yang digunakan adalah sebagai berikut.

\subsection{Observasi Pendahuluan}

Penelitian ini dilakukan di PT XYZ, pada tahap ini dilakukan penelitian di departemen Produksi. Penelitian dipusatkan pada salah satu proses produksi yaitu Assy Wheel. Penelitian dilakukan dengan mengamati secara langsung ke produksi seberapa besar penyebab tidak efisiensi yang terjadi dan apa penyebabnya.

\subsection{Identifikasi Permasalahan}

Identifikasi permasalahan adalah tahapan dalam menemukan dan mengenali objek permasalahan yang akan diteliti. Setelah melakukan pengamatan di Produksi Assy Wheel ditemukan masalah cycle time yang tidak seimbang pada lini Assy Wheel.

\subsection{Tinjauan Pustaka}

Tinjauan pustaka dilakukan dengan cara mempelajari konsep aktivitas dalam melakukan penelitian dengan landasan teori yang berisi teori-teori yang dapat menunjang penelitian untuk membantu memecahkan masalah yang ada tanpa keluar dari ruang lingkup batasan masalah yang telah dibuat sebelumnya. Pada penelitian ini untuk menyeimbangkan pada lintasan perakitan metode yang digunakan adalah metode Helgeson - Birnie, nama yang lebih popular dari metode ini adalah metode posisi peringkat (Rank Positional Weight). Metode ini sesuai dengan namanya dikemukakan oleh Helgeson dan Birnie. Metode ini dipilih karena lebih mudah penerapannya dibandingkan metode yang lain (Perwitasari, 2018).

\subsection{Pengumpulan dan Pengolahan Data}

Dalam tahapan ini, dilakukan pengumpulan data. Sumber data penelitian terdiri atas data primer dan data sekunder. Data primer dikumpulkan degan melakukan pertemuan dengan pihak - pihak terkait yang digunakan untuk pengolahan data perencanaan produksi, Serta data sekunder dari tinjauan dokumen berupa jumlah order bulanan Wheel Assy dan data waktu kerja efektif bulanan lintasan produksi Wheel Assy.

\subsection{Analisis}

Pengolahan data dilakukan dengan mengamati sistem yang ada dan dianalisis informasi serta tindakan apa saja yang kurang selama ini sehingga dapat diketahui perbaikan apa yang akan dilakukan. Langkah awal yang dilakukan adalah membuat precedence diagram, kemudian melakukan pembobotan posisi dan terakhir membagi proses kerja ke stasiun kerja untuk mendapatkan keseimbangan lintasan (Wignjosoebroto, 2008).

\subsection{Kesimpulan}

Tahapan ini berisi kesimpulan yang didapat dari hasil penelitian yang dilakukan atas rumusan masalah yang telah ditentukan sebelumnya dan memberikan saran mengenai permasalahan yang ada dalam perusahaan yang ditemukan saat penelitian. 


\section{Hasil dan Diskusi}

\subsection{Pengenalan Produk dan Area Produksi}

Proses Assy Wheel merupakan proses perakitan roda dimana komponen-komponen dari supplier di rakit untuk menjadi sebuah Wheel Assy seperti pada Gambar 1. Pada satu unit Wheel Assy terdiri atas tiga komponen yaitu Tire, Casting Wheel, dan Valve Rim.

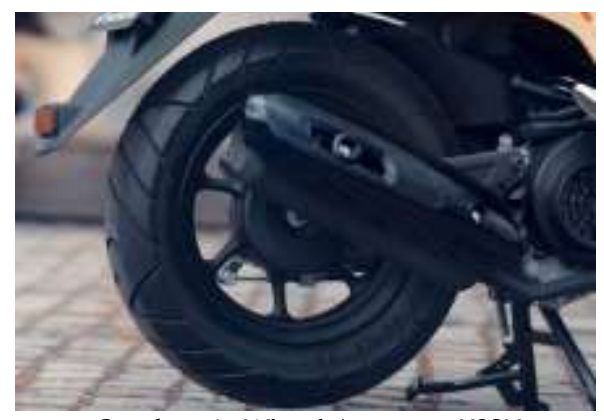

Gambar 1. Wheel Assy type K93X

Satu unit Wheel Assy terdiri atas tiga komponen yang di rakit pada Main Line dengan jumlah stasiun kerja yang melakukan proses perakitan terdapat empat stasiun. Berikut ini Layout dari proses Assy Wheel dapat dilihat pada Gambar 2.

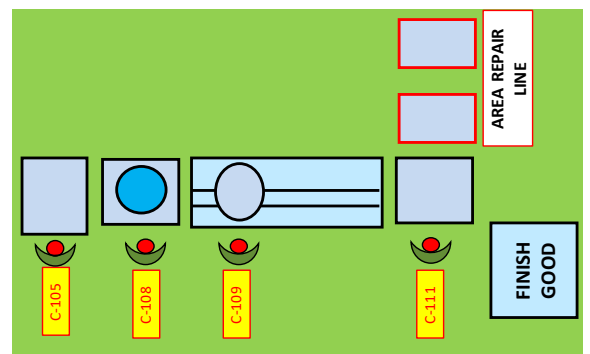

Gambar 2. Lintasan Assy Wheel type K93X

Pada Gambar 2, lintasan Assy Wheel, setiap stasiun kerja terdapat tenaga kerja yang melakukan pekerjaan sesuai dengan standar operasi yang telah ditentukan. Untuk kode C-105 merupakan stasiun Insert Valve, C-108 merupakan stasiun Tire Install, C-109 merupakan stasiun Air Filler, dan yang terakhir C-111 merupakan stasiun Final Inspection

\subsection{Pengamatan Faktor-faktor Penyesuaian}

Untuk menghitung waktu standar diperlukan faktor-faktor penyesuaian. Pemberian nilai dari faktor-faktor penyesuaian dilakukan pada Line Wheel Assy diambil berdasarkan pengamatan dari empat operator, satu operator sebagai Final Inspection memiliki skill dan komunikasi yang lebih dari operator yang lain dan sebagai acuan pemberian faktor-faktor penyesuaian. (Sutalaksana, I. Z., Jann H. Tjakraatmadja, dan Ruhana Anggawisastra. 1979.) Untuk mengetahui keseluruhan nilai faktor penyesuain pada masing-masing operator dapat dilihat pada Tabel 1.

\subsection{Pengamatan Faktor Kelonggaran}

Faktor-faktor kelonggaran diperlukan untuk menghitung waktu standar. Pemberian nilai dari faktor-faktor kelonggaran dilakukan berdasarkan pengamatan ketika proses produksi berlangsung dan diasumsikan sama untuk semua operator. Pada Tabel 2 dapat dilihat faktor kelonggaran untuk operator pada line Wheel Assy. 
Tabel 1. Faktor - faktor penyesuaian

\begin{tabular}{|c|c|c|c|c|c|}
\hline Station & Faktor & Kelas & Lambang & Penyesuaian & Jumlah \\
\hline \multirow{4}{*}{ Insert Valve } & Keahlian & Average & $\mathrm{D}$ & 0.00 & \multirow{4}{*}{0.00} \\
\hline & Usaha & Average & $\mathrm{D}$ & 0.00 & \\
\hline & Kondisi & Average & $\mathrm{D}$ & 0.00 & \\
\hline & Konsistensi & Average & $\mathrm{D}$ & 0.00 & \\
\hline \multirow{4}{*}{ Tire Install } & Keahlian & Good & $\mathrm{C} 2$ & 0.03 & \multirow{4}{*}{0.03} \\
\hline & Usaha & Average & $\mathrm{D}$ & 0.00 & \\
\hline & Kondisi & Average & $\mathrm{D}$ & 0.00 & \\
\hline & Konsistensi & Average & $\mathrm{D}$ & 0.00 & \\
\hline \multirow{4}{*}{ Air Filler } & Keahlian & Average & $\mathrm{D}$ & 0.00 & \multirow{4}{*}{0.00} \\
\hline & Usaha & Average & $\mathrm{D}$ & 0.00 & \\
\hline & Kondisi & Average & $\mathrm{D}$ & 0.00 & \\
\hline & Konsistensi & Average & D & 0.00 & \\
\hline \multirow{4}{*}{ Final Inspection } & Keahlian & Good & $\mathrm{C} 2$ & 0.03 & \multirow{4}{*}{0.03} \\
\hline & Usaha & Average & $\mathrm{D}$ & 0.00 & \\
\hline & Kondisi & Average & D & 0.00 & \\
\hline & Konsistensi & Average & $\mathrm{D}$ & 0.00 & \\
\hline
\end{tabular}

Tabel 2. Faktor - faktor kelonggaran

\begin{tabular}{|l|l|c|}
\hline \multicolumn{1}{|c|}{ Faktor } & \multicolumn{2}{c|}{ Allowance } \\
\hline Tenaga yang Dikeluarkan & Sangat Ringan & $6 \%$ \\
\hline Sikap Kerja & Berdiri diatas kaki & $1 \%$ \\
\hline Gerakan Kerja & Agak terbatas & $0 \%$ \\
\hline Kelelahan Mata & Pandangan yang terputus putus & $0 \%$ \\
\hline Keadaan Temperatur Tempat Kerja & Normal & $0 \%$ \\
\hline Keadaan Atmosfer & Baik & $0 \%$ \\
\hline Keadaan Lingkungan yang Baik & Siklus kerja berulang - ulang & $0 \%$ \\
\hline Kelonggaran Untuk Kebutuhan & Pria & $0 \%$ \\
\hline \multicolumn{1}{|c|}{ Total } & $7 \%$ \\
\hline
\end{tabular}

\subsection{Waktu Kerja Efektif}

Pada dasarnya waktu kerja normal produksi PT. XYZ saat ini adalah sebagai berikut:

1. Hari kerja produksi adalah 5 hari, yaitu hari Senin sampai hari Jum'at.

2. Waktu kerja produksi adalah dua shift, yaitu shift 1 dan shift 2.

Waktu kerja efektif merupakan waktu yang dapat digunakan untuk melakukan proses produksi. Waktu kerja efektif didapatkan dari pengurangan total waktu kerja normal dengan total waktu untuk melakukan line stop terencana. Pada Tabel 3 terdapat jam kerja efektif pada PT. XYZ.

Tabel 3. Waktu kerja efektif

Shift 1 (Senin - Jumat : $07.00 \mathrm{~s} / \mathrm{d} 16.00)$

\begin{tabular}{|l|c|}
\hline \multicolumn{1}{|c|}{ Uraian } & Waktu (menit) \\
\hline Waktu kerja normal (Senin-Jumat) & 540 \\
\hline Line stop terencana : & \\
\hline 1. P5M & 5 \\
\hline 2. Cleaning (5R) & 20 \\
\hline 3. Istisrahat 10 menit (10.00 \& 14.30) & 50 \\
\hline 4. Ishoma (Senin-Jumat : 11.50 s/d 12.40) & 85 \\
\hline Total line stop terencana : & 455 \\
\hline Waktu kerja efektif Shift 1 & \\
\hline
\end{tabular}


Shift 2 (Senin - Jumat : 16.00 s/d 00.00)

\begin{tabular}{|l|c}
\hline \multicolumn{1}{|c|}{ Uraian Kegiatan } & Waktu \\
\hline Waktu kerja normal (Senin-Jumat) & 480 \\
\hline Line stop terencana & \\
\hline 1. P5M & 5 \\
\hline 2. Cleaning (5R) & 10 \\
\hline 3. Istisrahat 10 menit (17.50 \& 21.50) & 20 \\
\hline 4. Ishoma (Senin-Jumat : 19.10 s/d 20.00) & 50 \\
\hline Total line stop terencana : & 85 \\
\hline Waktu kerja efektif Shift 2 & 395 \\
\hline
\end{tabular}

\subsection{Planning Produksi Wheel Assy}

Planning Produksi merupakan data jumlah barang yang harus diproduksi pada bulan tertentu. Berdasarkan Planning Produksi dapat diketahui jumlah produksi rata-rata setiap bulan. Data Planning Produksi akan menjadi acuan pada perhitungan cycle time yang harus dicapai oleh lintasan produksi. Sehingga Wheel Assy dapat diproduksi sesuai jumlah yang diinginkan. Pada Tabel 4 dapat dilihat Planning Produksi Wheel Assy.

Tabel 4. Planning produksi wheel assy

\begin{tabular}{|c|c|c|c|c|c|c|}
\hline Bulan & Jan-19 & Feb-19 & Mar-19 & Apr-19 & May-19 & Jun-19 \\
\hline Planning Produksi/Bulan & 50000 & 46000 & 50000 & 46000 & 50000 & 36000 \\
\hline Jumlah Hari Produksi & 25 & 23 & 25 & 23 & 25 & 18 \\
\hline Planning Produksi/Hari & 2000 & 2000 & 2000 & 2000 & 2000 & 2000 \\
\hline
\end{tabular}

\subsection{Data Cycle Time}

Pengambilan data Cycle Time dilakukan dengan metode jam henti dimana data diambil sebanyak 30 kali berturut-turut kemudian akan dilakukan pengolahan. Pengolahan data cycle time untuk memastikan data hasil waktu yang diambil telah cukup dan seragam.

Data perhitungan cycle time yang diambil adalah waktu kerja di setiap elemen kerja pada stasiun kerja proses perakitan Wheel Assy. Data diambil pada bulan Juni 2019 pada saat proses produksi Wheel Assy. Berikut pada Tabel 5

Tabel 5. Data Cycle Time Line Assy Wheel

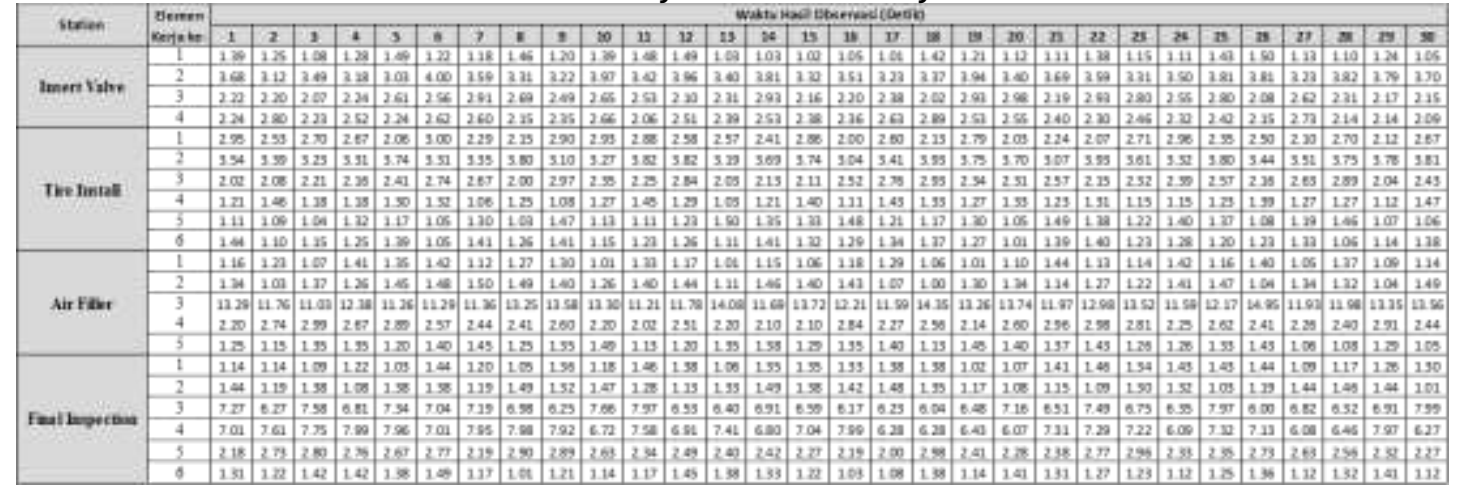

\subsection{Keseragaman Data}

Setelah mendapat data cycle time setiap elemen kerja pada stasiun kerja, maka langkah selanjutnya adalah melakukan uji keseragaman data. Tools yang digunakan adalah Control Chart. Pemeriksaan dilakukan dengan melihat apakah data yang ada masuk dalam range Batas Kontrol Atas (BKA) dan Batas Kontrol Bawah (BKB).

\subsection{Kecukupan Data}

Setelah data dinyatakan seragam dengan tidak adanya data berada di luar batas kendali, maka tahap selanjutnya adalah menguji kecukupan data. Pengujian kecukupan data berdasarkan tingkat ketelitian $5 \%$ dan tingkat keyakinan 95\%. Berikut ini pada Tabel 6 merupakan hasil uji keseragaman dan kecukupan data pada lintasan Assy Wheel. 
Tabel 6. Hasil Uji Kecukupan dan Keseragaman Data

\begin{tabular}{|c|c|c|c|c|c|c|c|c|c|c|c|c|c|c|}
\hline Station & \begin{tabular}{|l|} 
tlemen \\
Kerla ke-
\end{tabular} & Average & Std Dev & BKA & BKS & MaX & MIN & HASIL UII & $\sum \mathrm{N}$ & $\sum \times \mathrm{i}$ & $5 \times \mathrm{CH}^{2}$ & $(\Sigma \times j)^{2}$ & $N^{\prime}$ & $\begin{array}{c}\text { UII } \\
\text { KECUKUPAN }\end{array}$ \\
\hline \multirow{4}{*}{ Insert Valve } & 1 & 1.23 & 0.17 & 1.57 & 0.898161 & 1.497 & 1.007 & SERAGAM & 30 & 36.985 & 46.4084 & 1367.89 & 28.4949 & CUKUP \\
\hline & 2 & 3.54 & 0.28 & 4.10 & 2.9800739 & 4 & 3.03 & SERAGAM & 30 & 106.2 & 378.216 & 11278.4 & 9.6507 & CUKUP \\
\hline & 3 & 246 & 0.31 & 3.08 & 1.839747 & 298 & 202 & SERAGAM & 30 & 73.78 & 184.233 & 5443.49 & 24.5418 & CUKUP \\
\hline & 4 & 2.41 & 0.2 & 2.85 & 1.977881 & 2.89 & 2.06 & SERAGAM & 30 & 72.39 & 176.05 & 5240.31 & 12.573 & CUKUP \\
\hline \multirow{6}{*}{ Tire Instal } & 1 & 252 & 0.33 & 3.17 & 1.850999 & 3 & 2 & SERAGAM & 30 & 75.45 & 192.877 & 5692.7 & 26.3069 & cukup \\
\hline & 2 & 3.54 & 0.27 & 4.06 & 2.904475 & 393 & 304 & SERAGAM & 30 & 106.15 & 377.739 & 11267.8 & 9.13504 & cusup \\
\hline & 3 & 240 & 0.30 & 2.99 & 1.803835 & 291 & 2 & SERAGAM & 30 & 71.58 & 175.275 & 5181.12 & 23.8187 & CUKUP \\
\hline & 4 & 1.26 & 0.12 & 1.50 & 1.018548 & 1.467 & 1031 & SERAGAM & 30 & 30.722 & 47.8453 & 1422.95 & 13.9524 & curup \\
\hline & 5 & 1.24 & 0.16 & 1.55 & $0.925 / 53$ & 1.498 & 1.029 & SERAGAM & 30 & 37.144 & 46.6967 & 1379.68 & 24.6133 & CUKUP \\
\hline & 6 & 1.26 & 0.12 & 1.50 & 1.017123 & 1.437 & 1.014 & SERAGAM & 30 & 37.828 & 48.1296 & 1430.96 & 14.4562 & CUKUP \\
\hline \multirow{5}{*}{ Air Filler } & 1 & 1.20 & 0.14 & 1.48 & 0.920246 & 1.438 & 1.008 & SERAGAM & 30 & 36.022 & 43.8232 & 1297.58 & 21.0995 & CUKUPP \\
\hline & 2 & 1.31 & 0.16 & 1.62 & 0.991248 & 1.495 & 1,003 & SERAGAM & 30 & 39.238 & 52.0478 & 1539.62 & 22.6684 & CUKUP \\
\hline & 3 & 12.60 & 1.08 & 1477 & 10.44207 & 14.95 & 11.03 & SERAGAM & 30 & 378.13 & 4799.97 & 142982 & 11.3793 & CUKUP \\
\hline & 4 & 250 & 0.2 & 3.09 & 1.915823 & 299 & 202 & SERAGAM & 30 & 75.09 & 190.45 & 5638.51 & 21.2791 & cuKuP \\
\hline & 5 & 1.30 & 0.12 & 1.54 & 1.046306 & 1.489 & 1.047 & SERAGAM & 30 & 3.864 & 50.7971 & 1510.41 & 14.3035 & CUKLPP \\
\hline \multirow{6}{*}{ Final Inspection } & 1 & 1.26 & 0.15 & 1.56 & 0.96634 & 1.463 & 1.016 & SERAGAM & 30 & 37.938 & 48.6213 & 1439.29 & 21.509 & cukup \\
\hline & 2 & 1.30 & 0.15 & 1.60 & 0.993783 & 1.494 & 1.006 & SERAGAM & 30 & 3 조. 856 & 50.985 & 1509.79 & 20.9411 & CUKUP \\
\hline & 3 & 6.87 & 0.59 & 8.06 & 5.681158 & 799 & 6 & SERAGAM & 30 & 205.98 & 1424.44 & 42427.8 & 11.5146 & CUKuP \\
\hline & 4 & 7.13 & 0.66 & 8.45 & 5.804977 & 799 & 6.07 & SERAGAM & 30 & 213.83 & 1536.79 & 45723.3 & 13.3155 & cuKup \\
\hline & 5 & 2.52 & 0.27 & 3.06 & 1.966303 & 298 & 2 & SERAGAM & 30 & 75.6 & 192.577 & 5715.36 & 17.3411 & cuKup \\
\hline & 6 & 1.26 & 0.13 & 1.53 & 0.996164 & 1.485 & 1.007 & SERAGAM & 30 & 37.856 & 48.2811 & 1433.08 & 17.1435 & CUKUP \\
\hline
\end{tabular}

\subsection{Waktu Normal dan Waktu Standar}

Waktu standar merupakan waktu standar yang digunakan dalam rangkaian proses perakitan Wheel Assy. Untuk menentukan waktu standar dan waktu normal akan digunakan performance rating dan allowance yang telah ditentukan sebelumnya dari hasil observasi.

Waktu normal untuk suatu operasi kerja adalah semata - mata menunjukkan bahwa seorang operator yang berkualitas baik akan bekerja menyelesaikan pekerjaan pada kecepatan atau tempo kerja yang normal.

Waktu standar adalah waktu yang dibutuhkan oleh seorang pekerja yang memiliki tingkat kemampuan ratarata untuk menyelesaikan suatu pekerjaan, dengan memperhitungkan waktu kelonggaran sesuai dengan situasi dan kondisi pekerjaan yang harus diselesaikan tersebut. Hasil perhitungan waktu standar untuk setiap stasiun kerja dapat dilihat pada Tabel 7.

Tabel 7. Waktu Normal dan Waktu Standar

\begin{tabular}{|c|c|c|c|c|c|c|c|c|c|c|}
\hline \multirow{2}{*}{ Station } & \multirow{2}{*}{\begin{tabular}{|c|} 
Elemen \\
Kerja ke-
\end{tabular}} & \multirow{2}{*}{$\bar{x}$} & \multicolumn{4}{|c|}{ Performance Ratings } & \multirow{2}{*}{ Total Performance Ratings } & \multirow{2}{*}{ Waktu Normal } & \multirow{2}{*}{ Allowance } & \multirow{2}{*}{ Waktu Standar } \\
\hline & & & Keahlian & Usaha & Kondisi & Konsistens & & & & \\
\hline \multirow{4}{*}{ Insert Valve } & 1 & 1.23 & 0.00 & 0.00 & 0.00 & 0.00 & 0.00 & 1.23 & 0.07 & 1.32 \\
\hline & 2 & 3.54 & 0.00 & 0.00 & 0.00 & 0.00 & 0.00 & 3.54 & 0.07 & 3.79 \\
\hline & 3 & 2.46 & 0.00 & 0.00 & 0.00 & 0.00 & 0.00 & 2.46 & 0.07 & 2.63 \\
\hline & 4 & 2.41 & 0.00 & 0.00 & 0.00 & 0.00 & 0.00 & 2.41 & 0.07 & 2.58 \\
\hline \multirow{6}{*}{ Tire Install } & 1 & 2.52 & 0.03 & 0.00 & 0.00 & 0.00 & 0.03 & 2.59 & 0.07 & 2.77 \\
\hline & 2 & 3.54 & 0.03 & 0.00 & 0.00 & 0.00 & 0.03 & 3.64 & 0.07 & 3.90 \\
\hline & 3 & 2.40 & 0.03 & 0.00 & 0.00 & 0.00 & 0.03 & 2.47 & 0.07 & 2.64 \\
\hline & 4 & 1.26 & 0.03 & 0.00 & 0.00 & 0.00 & 0.03 & 1.30 & 0.07 & 1.39 \\
\hline & 5 & 1.24 & 0.03 & 0.00 & 0.00 & 0.00 & 0.03 & 1.28 & 0.07 & 1.36 \\
\hline & 6 & 1.26 & 0.03 & 0.00 & 0.00 & 0.00 & 0.03 & 1.30 & 0.07 & 1.39 \\
\hline \multirow{5}{*}{ Air Filler } & 1 & 1.20 & 0.00 & 0.00 & 0.00 & 0.00 & 0.00 & 1.20 & 0.07 & 1.28 \\
\hline & 2 & 1.31 & 0.00 & 0.00 & 0.00 & 0.00 & 0.00 & 1.31 & 0.07 & 1.40 \\
\hline & 3 & 12.60 & 0.00 & 0.00 & 0.00 & 0.00 & 0.00 & 12.60 & 0.07 & 13.49 \\
\hline & 4 & 2.50 & 0.00 & 0.00 & 0.00 & 0.00 & 0.00 & 2.50 & 0.07 & 2.68 \\
\hline & 5 & 1.30 & 0.00 & 0.00 & 0.00 & 0.00 & 0.00 & 1.30 & 0.07 & 1.39 \\
\hline \multirow{6}{*}{ Final Inspection } & 1 & 1.26 & 0.03 & 0.00 & 0.00 & 0.00 & 0.03 & 1.30 & 0.07 & 1.39 \\
\hline & 2 & 1.30 & 0.03 & 0.00 & 0.00 & 0.00 & 0.03 & 1.33 & 0.07 & 1.43 \\
\hline & 3 & 6.87 & 0.03 & 0.00 & 0.00 & 0.00 & 0.03 & 7.07 & 0.07 & 7.57 \\
\hline & 4 & 7.13 & 0.03 & 0.00 & 0.00 & 0.00 & 0.03 & 7.34 & 0.07 & 7.86 \\
\hline & 5 & 2.52 & 0.03 & 0.00 & 0.00 & 0.00 & 0.03 & 2.60 & 0.07 & 2.78 \\
\hline & 6 & 1.26 & 0.03 & 0.00 & 0.00 & 0.00 & 0.03 & 1.30 & 0.07 & 1.39 \\
\hline
\end{tabular}

\subsection{Data Cycle Time Line Wheel Assy K93X}

Berdasarkan perhitungan pada subbab sebelumnya didapatkan waktu standar setelah memasukkan faktor penyesuaian dan faktor kelonggaran. Berikut ini adalah Gambar 3 data cycle time Line Wheel Assy K93X. 


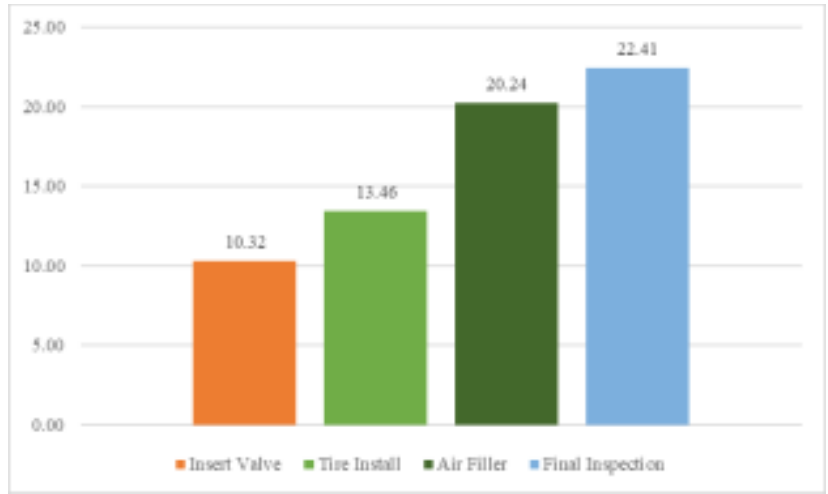

Gambar 3. Data Cycle Time Line Wheel Assy K93X

Berdasarkan grafik di atas dapat diketahui saat ini Cycle Time Line Wheel Assy K93X adalah 22.41 detik. Sehingga dapat diketahui kapasitas produksi lintasan produksi Wheel Assy saat ini adalah 38.915 Unit/Bulan. Jumlah ini cukup untuk memenuhi kebutuhan Planning Produksi Wheel Assy pada bulan Juni 2019 sebesar 36000 unit. Namun dengan melihat dari data Cycle Time yang ada, perlu dilakukan efisiensi pada lintasan produksi Wheel Assy dengan melakukan keseimbangan lintasan sehingga dapat meminimalisir jumlah stasiun kerja yang melakukan produksi.

\subsection{Perhitungan Target Takt Time Line Wheel Assy}

Untuk mencapai sebuah target produksi yang diinginkan harus terlebih dahulu menentukan cycle time sebuah produk. Cycle time dihitung berdasarkan waktu kerja dibagi dengan jumlah order sehingga menghasilkan sebuah waktu yang harus dicapai pada lintasan produksi agar target produksi dapat tercapai.

$\begin{array}{ll}\text { Jumlah produksi bulan Juni } 2019 & : 36000 \text { Unit } \\ \text { Jumlah jam kerja } & : 14.2 \text { Jam } \\ \text { Jumlah hari kerja } & : 95 \% \\ \text { Efisiensi lintasan } & : 94 \text { Kerja }\end{array}$

Target Cycle Time Line Wheel Assy:

$=(14.2 \times 18 \times 95 \%$ × 3600 $) / 36000)$

$=24.22$ detik

Berdasarkan perhitungan di atas didapat takt time pada lintasan produksi Wheel Assy adalah 24.22 detik.

\subsection{Performansi Keseimbangan Lintasan}

Setelah mengetahui waktu setiap stasiun kerja. Selanjutnya akan dilakukan penghitungan performansi keseimbangan lintasan dari Line Wheel Assy. Berikut ini adalah perhitungannya secara lengkap.

a. Efisiensi Stasiun Kerja (Station Efficiency)

Station Efficiency $=10.32 / 22.41 \times 100 \%$

Station Efficiency $=46 \%$

Setelah diketahui efisiensi dari masing-masing stasiun kerja, hasil perhitungan efisiensi stasiun kerja dapat dilihat pada Tabel 8.

b. Efisiensi Lintasan (Line Efficiency)

Line Efficiency $=66.42 /(22.41 \times 4) \times 100 \%$

Line Efficiency $=74 \%$

Senada dengan yang terjadi pada efisiensi stasiun kerja, efisiensi lintasan juga akan rendah jika efisiensi stasiun kerja rendah. Hal ini ditunjukkan dengan hasil perhitungan, di mana efisiensi lintasan sebesar $74 \%$ dari efisiensi maksimal $100 \%$. Hal ini juga menunjukkan bahwa lintasan bisa lebih dioptimalkan untuk meningkatkan efisiensi lintasan, yang nantinya diharapkan dapat mengefisienkan jumlah stasiun kerja. 
Tabel 8. Hasil perhitungan efisiensi stasiun kerja

\begin{tabular}{|c|c|c|c|}
\hline ration & 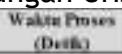 & $\begin{array}{l}\text { Waktu Prow, } \\
\text { Tertara (Itis) }\end{array}$ & Bhiensi \\
\hline Inser valise & 10.52 & 22.41 & $40 \%$ \\
\hline Tore insalt & 1346 & 2241 & $60 \%$ \\
\hline Air Filler & 2024 & 2241 & 90: \\
\hline Nual lesyectien & 22.41 & 22.41 & $100 \%$ \\
\hline
\end{tabular}

c. Waktu Menganggur (Idle Time)

Waktu menganggur (Idle Time) merupakan salah satu yang sangat dihindari pada sebuah sistem manufaktur. Karena idle time adalah salah satu penyebab ketidakefisienan sebuah sistem. Sehingga diupayakan semua proses manufaktur tidak mempunyai waktu menganggur. Berikut ini terdapat contoh perhitungan waktu menganggur.

Idle Time $=(4 \times 22.41)-66.42$

Idle Time $=23.22$ Detik

d. Balance Delay

Imbas dari besarnya waktu menganggur, berakibat pada tingginya nilai balance delay atau nilai ketidakefisienan suatu lintasan. Idealnya, sebuah lintasan seharusnya mempunyai balance delay $0 \%$. Berikut ini perhitungan dari balance delay.

$D=(4 \times 22.41)-66.42 / 4 \times 22.41$

$D=26 \%$

e. Smoothness Index

Dalam sebuah lintasan perakitan diharapkan perakitan dapat berjalan lancar tanpa ada waktu delay di salah satu stasiun kerja. Kondisi seperti ini dalam smoothness index ditunjukkan dengan angka indeks 0 (nol) atau biasa disebut perfect balance. Berikut ini perhitungan dari smoothness index Line Wheel Assy

$$
\begin{aligned}
& \mathrm{SI}=\sqrt{(22.41-10.32)^{2}+(22.41-13.46)^{2}+(22.41-20.24)^{2}+(22.41-22.41)^{2}} \\
& \mathrm{SI}=15.20
\end{aligned}
$$

Berdasarkan hasil pengumpulan dan pengolahan data di atas maka dapat diketahui bahwa Line Wheel Assy dapat dilakukan perbaikan untuk mengefisiensi jumlah stasiun kerja. Berikut ini pada Tabel 9 dapat diketahui hasilnya.

Tabel 9. Hasil perhitungan efisiensi stasiun kerja

\begin{tabular}{|c|c|c|c|c|}
\hline $\begin{array}{c}\text { Effisiensi Stasiun } \\
\text { Kerja }\end{array}$ & $\begin{array}{c}\text { Effisiensi } \\
\text { Lintasan }\end{array}$ & $\begin{array}{c}\text { Waktu } \\
\text { Menganggur }\end{array}$ & Balance Delay & $\begin{array}{c}\text { Smoothness } \\
\text { Index }\end{array}$ \\
\hline Minimum 46\% & $74 \%$ & 23.22 Detik & $26 \%$ & 15.2 \\
\hline
\end{tabular}

\subsection{Precedence Diagram}

Berdasarkan pengolahan data yang sudah dilakukan seperti di atas, dapat diketahui bahwa adanya cycle time yang tidak seimbang dan keseimbangan lintasan masih buruk. Sehingga kemampuan produksi menjadi tidak optimal. Oleh karena itu, rencana perbaikan dengan menggunakan metode Line Balancing. Line Balancing yang digunakan adalah metode Rank Positional Weight Helgeson-Birnie. Langkah- langkah perbaikan yang dilakukan yang pertama adalah membuat Precedence Diagram. Berikut ini pada Gambar 4 adalah precedence diagram dari proses Assy Wheel. 


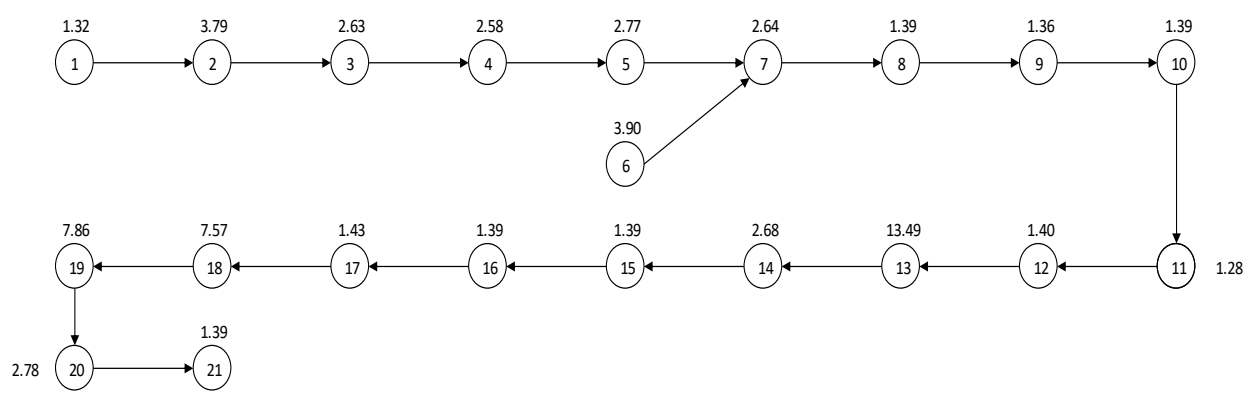

Gambar 4. Precedence diagram line wheel assy

\subsection{Pembobotan Posisi}

Setelah membuat precedence diagram dan mengetahui urutan proses, langkah selanjutnya adalah membuat pembobotan posisi. Pembobotan dilakukan dengan membuat matriks keterkaitan setiap proses. Berikut ini pada Tabel 10 matriks keterkaitan dan matriks pembobotan yang telah dibuat.

Tabel 10. Pembobotan posisi

\begin{tabular}{|c|c|c|c|c|c|c|c|c|c|c|c|c|c|c|c|c|c|c|c|c|c|c|}
\hline \multirow{2}{*}{$\begin{array}{l}\text { Elemen Kerja } \\
\text { Pendahulu }\end{array}$} & \multicolumn{21}{|c|}{ Elemen Kerja Pengikut } & \multirow{2}{*}{ Total } \\
\hline & 1 & 2 & 3 & 4 & 5 & 6 & 7 & 8 & 9 & 10 & 11 & 12 & 13 & 14 & 15 & 16 & 17 & 18 & 19 & 20 & 21 & \\
\hline 1 & & 3.79 & 2.63 & 2.58 & 2.77 & & 2.64 & 1.39 & 1.36 & 5.39 & 1.28 & 1.40 & 13.49 & 2.68 & 1.39 & 1.39 & 1.43 & 7.57 & 7.86 & 2.78 & 1.39 & 61.20 \\
\hline 2 & & & 2.63 & 2.58 & 2.77 & & 2.64 & 1.39 & 1.36 & 1.39 & 1.28 & 1.40 & 13.49 & 2.68 & 1.39 & 1.39 & 1.43 & 7.57 & 7.86 & 2.78 & 1.39 & 57.42 \\
\hline 3 & & & & 2.58 & 2.77 & & 2.64 & 1.39 & 1.36 & 1.39 & 1.28 & 1.40 & 13.49 & 2.68 & 1.39 & 1.39 & 1.43 & 7.57 & 7.86 & 2.78 & 1.39 & 54.78 \\
\hline 4 & & & & & 2.77 & & 2.64 & 1.39 & 1.36 & 1.39 & 1.28 & 1.40 & 13.49 & 2.68 & 1.39 & 1.39 & 1.43 & 7.57 & 7.86 & 2.78 & 1.39 & 52.20 \\
\hline 5 & & & & & & & 2.64 & 1.39 & 1.36 & 5.39 & 1.28 & 1.40 & 13.49 & 2.68 & 1.39 & 1.39 & 1.43 & 7.57 & 7.86 & 2.78 & 1.39 & 49.43 \\
\hline 6 & & & & & & & 2.64 & 1.39 & 1.36 & 1.39 & 1.28 & 1.40 & 13.49 & 2.68 & 1.39 & 1.39 & 1.43 & 7.57 & 7.86 & 2.78 & 1.39 & 49.43 \\
\hline 7 & & & & & & & & 1.39 & 1.36 & 1.39 & 1.28 & 1.40 & 13.49 & 2.68 & 1.39 & 1.39 & 1.43 & 7.57 & 7.86 & 2.78 & 1.39 & 46.79 \\
\hline 8 & & & & & & & & & 1.36 & 1.39 & 1.28 & 1.40 & 13.49 & 2.68 & 1.39 & 1.39 & 1.43 & 7.57 & 7.86 & 2.78 & 1.39 & 45.40 \\
\hline 9 & & & & & & & & & & 1.39 & 1.28 & 1.40 & 13.49 & 2.68 & 1.39 & 1.39 & \begin{tabular}{|l|} 
\\
\end{tabular} & 7.57 & 7.86 & 2.78 & 1.39 & 44.04 \\
\hline 10 & & & & & & & & & & & 1.28 & 1.40 & 13.49 & 2.68 & 1.39 & 1.39 & 1.43 & 7.57 & 7.86 & 2.78 & 1.39 & 42.65 \\
\hline 11 & & & & & & & & & & & & 1.40 & 13.49 & 2.68 & 1.39 & 1.39 & \begin{tabular}{|l|}
1.43 \\
\end{tabular} & 7.57 & 7.86 & 2.78 & 1.39 & 41.36 \\
\hline 12 & & & & & & & & & & & & & 13.49 & 2.68 & 1.39 & 1.39 & 1.43 & 7.57 & 7.86 & 2.78 & 1.39 & 39.96 \\
\hline 13 & & & & & & & & & & & & & & 2.68 & 1.39 & 1.39 & \begin{tabular}{|l|} 
\\
\end{tabular} & 7.57 & 7.86 & 2.78 & 1.39 & 26.48 \\
\hline 14 & & & & & & & & & & & & & & & 1.39 & 1.39 & \begin{tabular}{|l|} 
\\
\end{tabular} & 7.57 & 7.86 & 2.78 & 1.39 & 23.80 \\
\hline 15 & & & & & & & & & & & & & & & & 1.39 & \begin{tabular}{|l|} 
\\
\end{tabular} & 7.57 & 7.86 & \begin{tabular}{|l}
2.78 \\
\end{tabular} & \begin{tabular}{l|l}
3.39 \\
\end{tabular} & 22.41 \\
\hline 16 & & & & & & & & & & & & & & & & & 1.43 & 7.57 & 7.86 & 2.78 & $\begin{array}{l}3.39 \\
\end{array}$ & 21.02 \\
\hline 17 & & & & & & & & & & & & & & & & & & 7.57 & 7.86 & 2.78 & 1.39 & 19.59 \\
\hline 18 & & & & & & & & & & & & & & & & & & & 7.86 & 2.78 & $\begin{array}{l}3.39 \\
\end{array}$ & 12.02 \\
\hline 19 & & & & & & & & & & & & & & & & & & & & 2.78 & 1.39 & 4.17 \\
\hline 20 & & & & & & & & & & & & & & & & & & & & & 1.39 & 1.39 \\
\hline 21 & & & & & & & & & & & & & & & & & & & & & & 0.00 \\
\hline
\end{tabular}

\subsection{Membagi Proses Kerja ke Stasiun Kerja}

Setelah diketahui bobot posisi setiap elemen kerja dan sudah diurutkan berdasarkan bobot posisi setiap elemen kerja, selanjutnya dilakukan pengelompokan elemen kerja sesuai urutan dan dengan batas maksimal waktu stasiun kerja sesuai dengan target cycle time yang sudah dihitung. Berikut ini Tabel 11 pembagian stasiun kerja dengan target cycle time $\mathbf{2 4 . 2 2}$ detik sesuai urutan bobot posisi.

Setelah dilakukan pembagian elemen kerja maka saat ini hanya terdapat tiga stasiun kerja dengan pola keseimbangan lintasan baru.

\subsection{Perubahan Layout dan Pengilangan Shutter}

Dengan adanya perubahan jumlah stasiun kerja dan elemen kerja yang dilakukan oleh operator. Maka Layout Line Wheel Assy juga mengalami perubahan dengan menyesuaikan elemen kerja yang harus dilakukan oleh operator Wheel Assy. Layout Line Wheel Assy setelah perbaikan dapat dilihat pada Gambar 5.

Setelah dilakukan perubahan Layout maka elemen kerja pada Line Wheel Assy juga berubah dengan hilangnya proses transfer part ke shutter yaitu elemen kerja ke-5 sebesar (2,77 detik). Sehingga secara keseluruhan cycle time insert valve dan Tire Install menjadi 23,77 - 2,77 = 21 detik. Gambar 6 berikut adalah cycle time Line Wheel Assy setelah perbaikan secara keseluruhan. 
Tabel 11. Pembagian Proses Kerja ke Stasiun Kerja Batu

\begin{tabular}{|c|c|c|c|}
\hline Station & Elemen Kerja & Waktu Standar & Cycle time \\
\hline \multirow{10}{*}{$\begin{array}{c}\text { Insert valve and } \\
\text { Tire Install }\end{array}$} & 1 & 1.32 & \multirow{10}{*}{23.77} \\
\hline & 2 & 3.79 & \\
\hline & 3 & 2.63 & \\
\hline & 4 & 2.58 & \\
\hline & 5 & 2.77 & \\
\hline & 6 & 3.90 & \\
\hline & 7 & 2.64 & \\
\hline & 8 & 1.39 & \\
\hline & 9 & 1.36 & \\
\hline & 10 & 1.39 & \\
\hline \multirow{5}{*}{ Air Filler } & 1 & 1.28 & \multirow{5}{*}{20.24} \\
\hline & 2 & 1.40 & \\
\hline & 3 & 13.49 & \\
\hline & 4 & 2.68 & \\
\hline & 5 & 1.39 & \\
\hline \multirow{6}{*}{ Final Inspection } & 1 & 1.39 & \multirow{6}{*}{22.42} \\
\hline & 2 & 1.43 & \\
\hline & 3 & 7.57 & \\
\hline & 4 & 7.86 & \\
\hline & 5 & 2.78 & \\
\hline & 6 & 1.39 & \\
\hline
\end{tabular}

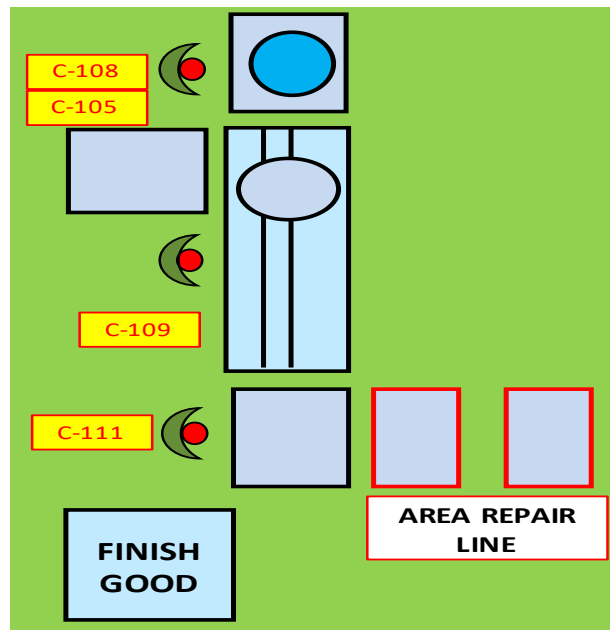

Gambar 5. Layout line wheel assy

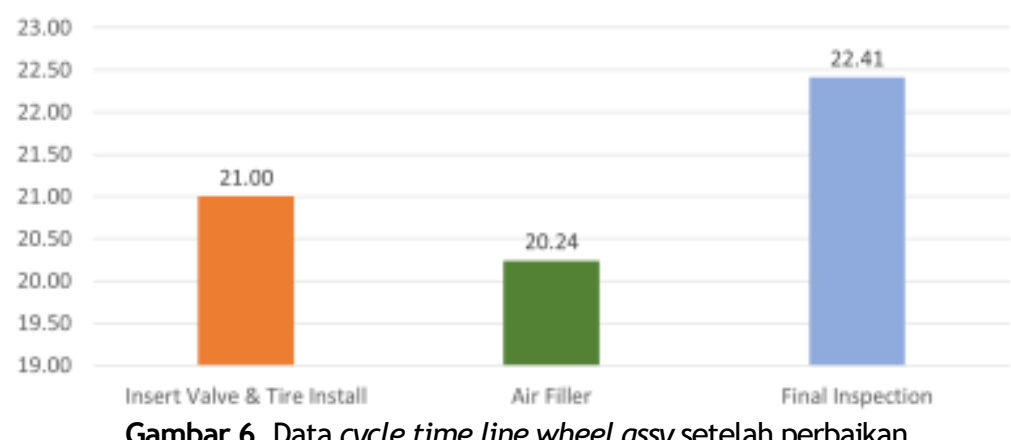

Gambar 6. Data cycle time line wheel assy setelah perbaikan

\subsection{Evaluasi Hasil Perbaikan}

Setelah melakukan perbaikan dengan metode line balancing, jumlah stasiun kerja pada Line Wheel Assy berkurang menjadi tiga stasiun kerja. Selain itu juga terdapat peningkatan performansi keseimbangan lintasan setelah dilakukan perbaikan dimana efisiensi lintasan semakin tinggi, waktu delay semakin rendah, dan 
kelancaran aliran proses semakin bagus yang ditunjukkan dengan rendahnya nilai smoothness index. Berikut ini pada Tabel 12 dapat dilihat Tabel perbandingan perfomansi lintasan setelah dilakukan perbaikan.

Tabel 12. Perbandingan hasil penghitungan performansi keseimbangan lintasan

\begin{tabular}{|c|c|c|c|c|c|}
\hline Kondisi & $\begin{array}{c}\text { Effisiensi } \\
\text { Stasiun Kerja }\end{array}$ & $\begin{array}{c}\text { Effisiensi } \\
\text { Lintasan }\end{array}$ & $\begin{array}{c}\text { Waktu } \\
\text { Menganggur }\end{array}$ & Balance Delay & $\begin{array}{c}\text { Smoothness } \\
\text { Index }\end{array}$ \\
\hline Sebelum Perbaikan & Minimum 46\% & $74 \%$ & 23.22 Detik & $26 \%$ & 15.2 \\
\hline Setelah Perbaikan & Minimum 90\% & $95 \%$ & 3.58 Detik & $5 \%$ & 2.59 \\
\hline
\end{tabular}

\section{Kesimpulan}

This Berdasarkan pengolahan data yang telah dilakukan, maka dapat disimpulkan, yaitu dengan menggunakan metode Line Balancing RPW (Ranked Positional Weight) dapat dilakukan perbaikan berupa penggabungan elemen kerja pada dua stasiun kerja asal. Dalam kasus penyeimbangan lintasan Line Wheel Assy, stasiun kerja pada Insert Valve dan Tire Install dapat dilakukan penggabungan sehingga cycle time yang didapat menjadi lebih seimbang. Dengan perbaikan ini maka dapat meningkatkan efisiensi lintasan Assy Wheel dari $74 \%$ menjadi 95\%, selain itu jumlah stasiun kerja dan tenaga kerja juga mengalami penurunan dari tiga menjadi dua tenaga kerja pada lintasan Assy Wheel.

\section{Daftar Pustaka}

1. Afifuddin, M. (2019). Penerapan Line Balancing Menggunakan Metode Ranked Position Weight (RPW) untuk Meningkatkan Output Produksi pada Home Industri Pembuatan Sepatu Bola. Journal of Industrial Engineering Management, 4(1), 38-4

2. Astuti, R. D., \& Edy purwanto, H. S. A., (2019). Perbaikan Line Balancing Proses Packing Tablet Xyz Menggunakan Metode Ranked Positional Weight Di Pt. Y. Performa: Media Ilmiah Teknik Industri, 18(1).

3. Azwir, H. H., Nugraha, A.F. (2020). Redesigning Assembly Line By Applying Ranked Positional Weight At Heavy-Industrial Facility. Spektrum Industri, 18(2), 133-144.

4. Kays, Emrul, et al., 2017. "Ranked sequence positional weight heuristic for simultaneous balancing and scheduling jobs in a distributed manufacturing environment" Kuala Lumpur: ScienceDirect

5. Manaye, M. (2019). Line Balancing Techniques for Productivity Improvement. International Journal of Mechanical and Industrial Technology, 7(1), 89-104.

6. Prabowo, R. (2016). Penerapan Konsep Line Balancing Untuk Mencapai Efisiensi Kerja Yang Optimal Pada Setiap Stasiun Kerja Pada PT. HM. Sampoerna Tbk. Jurnal IPTEK, 20(2), 9-19.

7. Perwitasari, D.S., (2018). Perbandingan Metode Ranked Positional Weight dan Kilbridge Wester Pada Permasalahan Keseimbangan Lini Lintasan Produksi Bebasis Single Model”. Bandung: Teknik Informatika. Institut Teknologi Bandung. Diakses dari: https://informatika.stei.itb.ac.id/ rinaldi.munir/TA/Makalah_TA\%20Dyah\%20Saptanti.pdf

8. Sutalaksana, I. Z., Tjakraatmadja, J.H. dan Anggawisastra, R., (1979). Teknik Tata Cara Kerja, Bandung: Penerbit Departemen Teknik Industri - ITB

9. Wignjosoebroto, S., (2008). Ergonomi, Studi Gerak dan Waktu: Teknik Analisis Untuk Peningkatan Produktivitas Kerja. Surabaya: Penerbit Guna Widya 